$\underline{\text { Jukka Tuomisto }}$

\title{
KIRJOITTAMINEN OPPIMISPROSESSIN APUNA
}

\begin{abstract}
Kirsti Lonka \& Irma Lonka (toim.) 1991. Aktivoiva opetus. Käsikirja aikuisten ja nuorten opettajille. Kirjayhtymä: Helsinki. $127 \mathrm{~s}$.
\end{abstract}

V aikka oppimispsykologinen tutkimus on edennyt viime vuosikymmeninä nopeasti, niin tämän tiedon välittyminen käytäntöön näyttää olevan hidas ja vaikea prosessi. Kirsti ja Irma Lonkan toimittama kirja Aktivoiva opetus pyrkii omalta osaltaan helpottamaan tätä prosessia. Kirjassa esitellään uuden kognitiotieteen keskeisimmät käsitteet ja perusperiaatteet sekä pyritään osoittamaan, kuinka näitä periaatteita voidaan soveltaa käytännön opetustilanteissa. Kirjan alaotsakkeen mukaan se on tarkoitettu nuorten ja aikuisten opettajille. Sen käyttäjäkunta on siis jaateltu varsin laajaksi. Kirjoittajat näyttävät asettaneen kuitenkin aikuisopettajat kirjan ensisijaiseksi kohderyhmäksi. Arvioin tästä syystä seuraavassa kirjaa lähinnä aikuiskasvatuksen ja -opetuksen näkökulmasta.

K irjan alussa lukija motivoidaan engeströmiläisen oikeaoppisesti herättämällä hänessä tiedollinen ristiriita kysymällä "'Oppimisnäkemys muuttuu entä koulutus?" Tämän jälkeen tuodaan lyhyesti esiin perinteisen suoritus- ja tulospainotteisen opetuksen heikkoudet ja riittämättömyys nykyisessä uuden tietotekniikan käyttöön perustuvassa informaatioyhteiskunnassa. Tähän ajatukseen on aikuiskasvattajien helppo yhtyä, sillä onhan aikuisopetuksessa perinteisesti korostettu enemmän opiskelijoiden omia tavoitteita ja heidän yksilöllisiä oppimisprosessejaan kuin ulkoapäin asetettuja tutkinto- tai suoritustavoitteita.

$\mathbf{K}$ irja jakautuu kolmeen osakokonaisuuteen. Luvussa 2. esitellään lyhyesti aktivoivan opetuksen peruskäsitteet ja -ajatukset. Tämän luvun on kirjoittanut Kirsti Lonka, joka toimii Helsingin yliopiston psykologian assistenttina. Esitys on tiivis, mutta informatiivinen. Siinä käsitellään tietorakenteiden ra- kentumista, ongelmanratkaisun eräitä peruslainalaisuuksia, opiskelustrategioita sekä opettajan ja opiskelijan uutta roolia opetus/oppimistilanteissa. Lopuksi esitellään kolme keskeistä periaatetta, jotka tulisi ottaa aina huomioon opetuskäytännöissä. Vaikka esitys ei tarjoakaan mitään kovin uutta - ei ainakaan sellaisille lukijoille, jotka ovat aikaisemmin perehtyneet kognitiiviseen oppimisteoriaan - niin kirjan kokonaisuutta ajatellen luku puolustaa hyvin paikkaansa. On myös muistettava, etteivät nämä perusajatukset ole vielä siirtyneet riittävän hyvin kaikkien aikuisopettajien pitkäaikaismuistiin ja tietorakenteisiin.

$\mathbf{K}^{\mathrm{i}}$ irjoittajan keskeisinä didaktisina perusajatuksina ovat opiskelijakeskeisyys ja oppimisen prosessiluonteisuus sekä opettajan roolin uudelleenarviointi. Kirsti Lonkan mukaan aktivoivalla opetuksella tarkoitetaan opetusta, jossa oppiminen on keskeisin tavoite. Tällöin vastuuta oppimisesta pyritään siirtämään opiskelijalle; opettaja toimii pikemminkin jonkinlaisena yhteistyökumppanina ja työn ohjaajana kuin tiedon jakajana (s. 12).

Tässä suhteessa voi todeta, ettei mitään uutta auringon alla, sillä onhan oppiminen ollut aina kaiken opetustoiminnan keskeisenä tavoitteena. Jo Comenius totesi aikoinaan, että opetusopin päämääränä on etsiä ja keksiä sellainen menettelytapa, että opettajan työ supistuisi vähempään, mutta oppilas kuitenkin oppisi enemmän. Samoin kasvatusteoreetikkojen näkemys kasvatuksesta "'kasvamaan saattamisena" korostaa opiskelijan omaa oppimisprosessia ja opettajan roolia tämän kasvuprosessin auttajana. Myös aikuiskasvatuksen teoreetikot ovat kautta aikojen korostaneet opiskelijakeskeisyyttä yhtenä toiminnan keskeisenä lähtökohtana sekä nähneet opettajan/ohjaajan roolin samaan tapaan kuin kirjoittaja (ks. esimerkiksi Knowles 1980). Tästä syystä he eivät ole mielellään puhuneet opettajasta tai kouluttajasta, vaan he ovat suosineet sellaisia termejä kuin 'facilitator" tai "'resource person" (ks. esimerkiksi Brookfield 1986, 123). 
$\mathbf{K}$ irjan didaktiset perusajatukset ovat siis lähes identtiset aikuisdidaktiikan perusajatusten kanssa. Kirjoittaja on päätynyt ajatuksiinsa kognitiotieteen tulosten perusteella, aikuiskasvattajat taas humanistisen psykologian ja pitkäaikaisen kokemuksensa perusteella. Kognitiivinen psykologia ja toiminnan teoria ovat ohjanneet jo jonkin aikaa myös aikuiskasvatuskäytäntöjen kehittämistä.

$\mathrm{J}$ okaisella tieteenalalla on luonnollisesti omat peruskäsitteenä, teoreettiset viitekehyksensä ja teoriansa. Kirjan kirjoittajien ajatukset kumpuavat ilmeisesti lähinnä yleisen psykologian ja kasvatustieteen tutkimuksesta ja ne liittyvät näiden tieteenalojen viitekehykseen ja skeemoihin. Kirjassa esitettyjen ajatusten liittäminen aikuiskasvatuksen tietorakenteisiin ja skeemoihin olisi parantanut huomattavasti sen käyttökelpoisuutta aikuisopetuksessa.

S euraavassa luvussa (luku 3.) esitellään luettelon$S$ omaisesti aktivoivia ja prosessipainotteisia työtapoja. Sen ovat kirjoittaneet Kirsti ja Irma Lonka. Vaikka aktivoivien työtapojen lyhyt esittely on varmasti paikallaan, niin olisi toivonut, että kirjoittajat olisivat jäsentäneet niitä jollain tavoin, esimerkiksi työtapojen kokonaisvaltaisuuden (tai jonkun muun kriteerin) mukaan. Nyt kun jotkin yksittäiset opetukselliset toimenpiteet (alkukoe, ensiluonnos) on esitelty samanarvoisina kuin eräät laajemmat ja kokonaisvaltaisemmat aktivointiin tähtäävät työtavat (esimerkiksi projektityöskentely), jää lukijalle varsin hajanainen ja jäsentymätön kuva aktivoivista työtavoista. Luettelomaisesti - aakkosjärjestyksessä esiteltyjen työtapojen erot ja yhtäläisyydet jäävät myös hämäriksi. Ne eroavat toisistaan joskus niin vähäisessä määrin, että on aiheellista kysyä, onko niitä syytä erottaa lainkaan toisistaan? Toisaalta tekijät eivät erottele työtapoja minään lopullisina menetelminä, vaan he lähtevät siitä, että niitä voi ja on syytä kehitellä itse vapaasti. Tämä onkin tietysti ainoa oikea suhtautumistapa. Jos keskeisimmät työtavat olisi tuotu selkeämmin esiin, niin lukijan olisi ollut helpompi siirtää ne omiin tietorakenteisiinsa.

Kun otetaan huomioon se, että kirjaa markkinoidaan erityisesti aikuisopettajille, niin ei voi olla ihmettelemättä sitä, että tekijät eivät ole perehtyneet lainkaan aikaisempaan aikuiskasvatuksen opetusmenetelmiä ja työtapoja koskevaan kirjallisuuteen. Näin voi päätellä siitä, että tällaisia teoksia ei esiinny lainkaan lähdeluettelossa. Niistä olisi löytynyt melkoinen joukko lisää ' aktivoivia työtapoja" ja vieläpä paremmin esiteltyinä ja jäsenneltyinä. Erityisen silmiinpistävä puute on erilaisten "aktivoivien" ryhmätyömenetelmien tuntemattomuus. Vaikka joihinkin niistä viitataan, niin niiden esittely jää kuitenkin hyvin ylimalkaiseksi. Suurelta osin esiteltävät työtavat ovat aikuisopettajille jo varmaan ennestään tuttuja. - Uuttakin toki kuitenkin löytyy.

Uutta ja mielenkiintoista kirjassa on se, että siinä esitellään useita erilaisia omakohtaiseen kirjoittamiseen perustuvia aktivoivia työtapoja. Kirjan keskeisin anti aikuisopettajille on epäilemättä näiden työtapojen esittelyssä. Tutkijat ovat viime vuosina kiinnostuneet entistä enemmän erilaisten tekstien, puheiden tai kielen käytön monitieteisestä tutkimisesta (diskurssianalyysi). Tämä on suunnannut myös monien opettajien mielenkiinnon kirjallisten tekstien tuottamiseen ja tulkitsemiseen sekä niiden käyttämiseen opetuksen ja oppimisen apuneuvona.

Näyttää siltä, että tiedon prosessointi kirjoittamalla soveltuu yhtä hyvin niin yleissivistävän koulun kuin korkeakoulujenkin tietopuoliseen opetukseen. Epäilemättä kirjallisilla tuotoksilla on käyttöä myös aikuisopetuksessa. Kirjassa ei kuitenkaan pohdita lainkaan sitä, minkälaisiin opetustilanteisiin ja minkälaisille aikuisopiskelijaryhmille nämä työtavat soveltuvat parhaiten. Tästä olisi toivonut ainakin jonkinlaista kannanottoa. Jonkinlaista osviittaa tästä tosin saa kirjassa olevien esimerkkien kautta. Vaikka kirjallisten tuotosten käyttö ei varmaankaan ratkaise kaikkia aikuisopetuksen ongelmia, ne tarjoavat kuitenkin monissa tapauksissa mahdollisuuden aikuisten oppimisprosessien aktivoimiseen. Tästä syystä näiden työtapojen soisi yleistyvän myös aikuisopetuksessa.

$\mathrm{K}$ olmannen kokonaisuuden muodostavat (luvut 4.-10.) yksittäiset esimerkit aktivoivien menetelmien soveltamisesta käytännön opetustyöhön. Kirjoittajina ovat kirjan toimittajien lisäksi Minna Lakkala ja Minna Rasila, Marjaana Lindeman sekä Maarit Piblman.

Artikkelit käsittelevät lähinnä ammatillisen keskiasteen, lukion ja korkeakoulujen opetusta. Parissa artikkelissa liikutaan sentään selkeämmin myös aikuisopetuksen piirissä (opettajien täydennyskoulutus ja tietotekniikan opetus aikuisille). Artikkelit ovat sinällään mielenkiintoista luettavaa, mutta kovin paljon uutta ajateltavaa ne eivät juuri tarjoa. Samat työtavat toistuvat niissä hiukan eri tilanteissa ja eri versioina. Aikuisopetuksen erityisongelmiin artikkeleissa ei juuri kiinnitetä huomiota, mikä on luonnollista, kun suurin osa niistä käsittelee nuorisoasteen koulutusta. Ainoastaan tietotekniikkakoulutusta käsittelevässä artikkelissa pohditaan jossain määrin opetusprosessia myös aikuisten kannalta, lähtien heidän kokemustaustoistaan, tietorakenteistaan ja työelämän heille asettamista oppimistarpeista. Kaiken kaikkiaan artikkeleista välittyy yllättävän perinteinen ja koulukeskeinen ajattelu, jota tosin pehmentää aktivoivien työtapojen käyttö. Missään 
artikkelissa ei tarkastella oppimista aikuiselle ominaisissa 'luonnollisissa oppimistilanteissa", vaan kaikki esimerkit on koottu käytännöstä irrallaan olevista koulutustilanteista. Näin opetuksen yhteydet käytäntöön jäävät lähes kokonaan problematisoimatta.

K irjan viimeisessä luvussa (luku 11.) Kirsti ja Irma I Lonka pohtivat vielä lyhyesti aktivoivan oppimisen asemaa tulevaisuuden koulutusmallina. He toteavat: ' Nykyisin opetuskäytänteet aikuiskoulutuksessa ovat yleisesti ottaen jäljessä yhteiskunnan tarpeista, paikoin pahastikin" (s. 125). Toteamukselle olisi antanut jonkinlaista pontta, jos kirjoittajat olisivat osoittaneet tuntevansa myös nämä nykyiset käytänteet. Nyt väite saa lukijan vain ihmettelemään, mihin he sen perustavat. Ilmeisesti siihen, että heidän mainitsemiaan aktivoivan opetuksen työtapoja ei käytetä heidän mielestään aikuisopetuksessa nykyisin riittävästi. Tämä voi pitää paikkansa aktivoivien kirjoitusmenetelmien suhteen, mutta aikuisopetuksen leimaaminen tästä syystä jälkeenjääneeksi on kyllä liian vahva yleistys. Väittäisin päinvastoin, että aikuisopetuksessa seurataan yleensä paljon nopeammin yhteiskunnallista kehitystä kuin esimerkiksi koulujärjestelmässä.

A ikuisopetuksessa on jo vuosikausia käytetty mo-

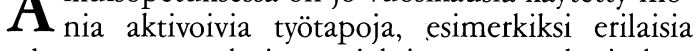
ryhmätyömenetelmiä, projektiopetusta, yhteisökasvatusta, kehittävää työntutkimusta jne. Voidaankin todeta, että monet aktivoivat opetusmenetelmät on omaksuttu ja kehitetty ensimmäiseksi juuri aikuisopetuksen piirissä, mistä niitä on alettu soveltamaan myös nuorten ja lasten opetukseen.
Kirjoittajat näyttävät olettavan, ettei nuorten ja aikuisten opetus/oppiminen poikkea mitenkään toisistaan. Kovin suuria eroja siinä ei varmaan havaitsekaan, jos aikuisopiskelijoiden erimerkkinä pidetään korkeakouluopiskelijoita. Jos kuitenkin vertaillaan esimerkiksi työssä jo kymmenkunta vuotta toimineita, keski-ikäisiä, perheellisiä henkilöitä ja lukiolaisia, nuorten ja aikuisten erot - sosiaaliset, psykologiset ja fysiologiset - tulevat jo selkeämmin esille. Näiden erojen huomioonottaminen olisi ollut paikallaan, kun kirjaa markkinoidaan myös aikuisopettajille.

$\mathbf{K}$ aiken kaikkiaan täytyy todeta, että lukijalle jää I kirjasta hieman hajanainen kokonaiskuva. Olisi ehkä ollut parempi, jos siinä olisi keskitytty selkeämmin erilaisten kirjoittamistekniikoiden käyttöön opetuksessa ja paneuduttu syvällisemmin niiden esittelyyn ja analysointiin. Nyt lukija jää kaipaamaan esimerkiksi kirjoittamisprosessin eri vaiheiden ja ongelmien tarkempaa esittelyä. Siitä huolimatta, että kirjan esimerkit ovat pääasiassa koulumaailman piiristä, olen vakuuttunut, että kirja tarjoaa myös aikuisopettajille uusia virikkeitä ja innostaa heitä oman opetuksensa kehittämiseen.

\section{LÄHTEET}

Brookfield, Stephen D. 1986. Understanding and Facilitating Adult Learning. San Francisco: Jossey-Bass Publishers.

Knowles, M.S. 1980. The modern Practice of Adult Education: from Pedagogy to Androgogy. New York: Association Press. 